\title{
Analysing of EFL Learners' Linguistic Errors: Evidence from Iranian Translation Trainees
}

\author{
Parisa Farrokh \\ Islamic Azad University of Lahijan Branch, Iran \\ Email: P_farrokh@Yahoo.com
}

\begin{abstract}
This paper aims to investigate the Linguistic errors of Iranian translation trainees. The question this study tries to answer is what the most frequent linguistic errors of English translation students are. To answer this question 50 junior students of translation training programme from the Islamic Azad University of Lahijan participated in the experiment. They were selected randomly from among 80 students who participated in an OPT general proficiency test. They were given 20 Persian sentences. The sentences were simple, declarative, affirmative and active. For the analysis of errors "Corder's" taxonomy was used. The analysis indicated that the errors resulting from wrong selection of words, permutation and errors of incorrect use of tenses were the most frequent errors respectively.
\end{abstract}

Index Terms - translator training, directionality, errors, error analysis

\section{INTRODUCTION}

During the years of experience, I have encountered many cases in which a number of students fail to present an acceptable translation of Persian sentences into English; moreover, these errors may be revealed in writing and even speaking of the learners. Therefore the linguistic errors found in this present study may help teachers and material designers choose an appropriate pedagogical method. It needs to be stressed here that this study seeks more to aid teachers of translation rather than professional translators, because obviously there are many discussions and view points about errors of translation and linguistic errors are only a portion of this sort. This research aims to study both global and local errors.

According to Burt and kiparsky (1974) a global error is one which involves the overall structure of a sentence like misuse of prepositions and a local error is one which affects a particular constituent such as omission of prepositions (P.73). Global and local errors which have been. considered in this research are omission and addition of definite and indefinite articles, omission and addition of plural "S", omission, addition and wrong selection of prepositions, omission of possessive "'S", third singular person "S", "Copula" and auxiliary verbs, wrong selection of "words", "parts of speech" and tenses and "misordering of elements". Corder's taxonomy has been used in this study. According to this taxonomy, both global and local errors can be classified. Errors in Corder's taxonomy (1973) have been classified according to their processes; i.e. ways in which errors are made or committed by language learners. There are four main processes in Corder's taxonomy: Omission (omission of some required element), Addition (addition of some unnecessary or incorrect element), Substitution (selection of an in correct element), and Permutation (misordering of elements)

\section{A. Translator Training and Directionality}

Translator training has undergone considerable changes since the beginning of the nineties, attempting to bridge the gap between the academic and professional worlds of translating. Scholars on translation teaching seem to agree that there is a difference between translation in foreign- language teaching and translation for professional purposes.

According to Menck (1991), translation in foreign- language teaching is a means to an end e.g. to facilitate the understanding of a text or test certain capabilities (i.e. grammar, vocabulary) in foreign language. In foreign- language teaching translation is therefore used to achieve purely the second language relevant. In contrast, translation for professional purposes is an end in itself.

It is a skill acquired on the basis of first and second language proficiency (Nord, 1991, P.140). Thus, professional translator should have sufficient knowledge in both languages.

According to linguistic knowledge of many English translating students (that they don't have adequate linguistic knowledge either in English or even in Persian) and also time limitation there is in the translation training programme we can not seek for professional purposes, whereas in most of Iran universities Language teaching is accompanied by translation instruction, and in fact translation is an instrument for language learning.

"Directionality" is another subject in translation which should be considered. According to Mahmoodzadeh (2003), in translation, directionality takes translator work into consideration, in other words, it defines whether translator translates from foreign language to native language or vice versa. 
At this point, it should be mentioned translation into the second language is rather controversial and frowned by many translation scholars and teachers. This is based on the assumption that most translators learned their mother tongue first and one or more foreign languages at a later stage. As a result, they are more confident comfortable and thus more efficient in their mother tongue. They are what Wilss (1982) calls compound bilinguals. In contrast, coordinate bilinguals have grown up or spent the better part of their childhood in a bilingual environment and are thus equally competent in both languages. It is therefore a widely held belief that only coordinate bilinguals should translate into a foreign language (P.59).

Unfortunately we have to say majority of the students believe that in translation, the native language is the target language. Even most of the teachers do not favourable opinion about translating from native language.

For example Mirza Ibrahim Tehrani (2003) believes that enforcing students to translate in foreign language does not contain only time and energy consuming, for the students do not have skills and knowledge about foreign language and in their translating make mistakes they had never been committed in their native language. She also eagers to omit translating to foreign language from translation training programme.

However it should be mentioned that the above attitude is contrary to translation practice since more than half of the work produced by translators is into the foreign language (Pym, 1992, P.36).

As a matter of fact for translating, constantly it is not possible to consider foreign language as source Language and native language as target language (Mahmood zadeh, 2003, P.44). For extra exercising and acquiring necessary skills it is better in translation classes students practice translating into the foreign language too.

Furthermore translations of this sort reveal the linguistic ability of language learners. As mentioned in introduction, most of these errors may be appeared in writing or speaking of foreign language learners. Thus, for students with poor language abilities translating becomes an instrument for foreign language learning (Nord, 1997, P.78).

\section{B. Errors and Error Analysis}

Before the 1960, when the behaviouristic view point of language was the dominant one, learner errors were considered as something undesirable.

With the appearance of the concept of "Universal Grammar" proposed by "Chomsky" (1957) and his rationalistic claim that human beings have innate capacity which can guide them through a vast number of sentence generation possibilities, cognitive approach instead of behaviouristic viewpoint was emphasized by many scholars. The largest contribution of this new linguistic theory of "Chomsky" is the interest it raised from researchers into learners' errors , as a means of hypothesis formation. Accordingly, a more favourable attitude has developed for error analysis during the $1970 \mathrm{~s}$ and $1980 \mathrm{~s}$. Toury (1995) mentions that Corder in 1967 was the first to advocate the importance of errors in the language learning process. He suggested that by classifying the errors that learners made, researchers can learn a great deal about the processes and strategies that language learners are used. Corder also believed that errors are systematic and reflect a defect in knowledge; i.e. linguistic competence (P.83). Regarding translation errors, there are different viewpoints. Errors in translation influence the quality of the final product and the degree of miscomprehension from the reader. Accordingly, translation errors are often judged based on their importance and frequency. According to Nord (1997), the most serious error in translation is pragmatic (P.78). Larose (1989) thinks that the textual level where the errors occur (superstructure, macro structure, microstructure) will decide the seriousness of the error, i.e. if the error occurs on a higher level of text, it is considered more serious (P.35). However Newmark (1988) simply divides most of the "mistakes" into two types: referential and linguistic. In his categorization, referential mistakes refer to all mistakes relation to facts or information in the real world. Linguistic mistakes, on the other hand, result from the translator's lack of proficiency in foreign language. Linguistic mistakes include words, collocations and idioms (P.189). In the case of second or foreign language learners, identifying translation error is harder, as translation errors may be mixed up with linguistic errors. When the translators are also language learners, the model of analyzing errors and translation assessment should be based on the learning model, which is a combination of training in linguistics at the same time on training in translation. Sager (1983) agrees that the most serious errors are those resulting from the incomepetence in a second language (P.125). Wilss (1982) also describes a translation error as "an offence against a norm in a linguistic contact situation" (P.201).

Regarding linguistic errors in translation Nord (1997) believes that they are caused by inadequate translation when the focus is on language structures. They represent deviations from standard target language paradigms and usages. Nord continues that for students with poor language abilities, the focus should be on linguistic correctness rather than communicative or functional appropriateness (P.75).

\section{METHOD}

The purpose of this study is to show the most frequent linguistic translation errors of Iranian translation students. This research deals with some global and local errors which are classified according to Corder's taxonomy into four main categories: omission, addition, substitution and permutation.

\section{A. Participants}


The participants of the study were 50 students of translation training programme studying at the Islamic Azad University of Lahijan, IRAN.

They were selected randomly from among 80students who participated in an OPT (Oxford Placement Test) general proficiency test. Their scores were below the average (below 50). All of them had passed the course of principles and methods of translation.

\section{B. Materials}

Twenty Persian sentences which were simple (contain one full subject and predicate), declarative, affirmative and active, were given and asked to translate into English. The sentences were contextually rich enough; because these sentences contained linguistic items which were going to be studied in this research. The tenses used in this study were the simple present tense, the present progressive tense, the present perfect tense, the simple past tense, the past progressive tense, the past perfect tense and the simple future tense.

\section{Procedures}

For the analysis of students, translation errors, Corder's taxonomy of errors was taken into consideration, i.e omission, addition, substitution and permutation.

1. Errors of Omission

1.1. Omission of the definite article "the"

* He has increased his awareness of - world.

1.2. Omission of the indefinite article "alan"

* John's father is now running - factory in New York.

1.3. Omission of preposition

* The little boy usually walks - home to school.

1.4. Omission of plural "s"

*They have come by a couple of small horse -.

1.5. Omission of the third singular person "s"

*John respect - the old man as a father.

1.6. Omission of possessive ",s "

*The soldier - parents saw their son on TV.

1.7. Omission of possessive pronoun

* He was playing with - elder brother.

1.8. Omission of copula

* Some kinds of goods - very cheap in my country.

1.9. Omission of auxiliary verb

* The government - continued its struggle against inflation since 1999.

2. Errors of Addition

2.1. Addition of the definite article "the"

* The most of the families go to the parks on Fridays.

2.2. Addition of indefinite article "alan"

*The soldier's parents saw their son on a TV.

2.3. Addition of preposition

* We visited from Mashhad two years ago.

2.4. Addition of plural "s"

* In Iran participations of womans in social activities are remarkable.

3. Errors of Substitution

3.1. Wrong selection of words

* She had made many wrongs in spelling.

3.2. Wrong selection of parts of speech

* His parents spoke to him with a loudness voice.

3.3. Wrong selection of tenses

* Most of the families are going to the parks on Fridays.

3.4. Wrong selection of preposition

* The little boy usually walks from home until school.

4. Errors of Permutation

4.1. Wrong order of elements

* They about the war a bad news received.

\section{FINDINGS}

The results of the translation's analysis along with a report on their frequencies have been illustrated as follows: 
TABLE 1.

NUMBER OF ERRORS OF OMISSION AND THEIR FREQUENCIES

\begin{tabular}{|c|c|c|c|c|}
\hline Errors of omission & $\begin{array}{l}\text { Number of correct } \\
\text { responses }\end{array}$ & $\begin{array}{l}\text { Number of wrong } \\
\text { responses }\end{array}$ & $\begin{array}{l}\text { Frequency of correct } \\
\text { responses }\end{array}$ & $\begin{array}{l}\text { Frequency of wrong } \\
\text { responses }\end{array}$ \\
\hline Omission of the definite article the & 377 & 50 & 68.54 & 27.28 \\
\hline Omission of the indefinite article "alan" & 82 & 57 & 41 & 28.5 \\
\hline Omission of plural "s " & 466 & 80 & 77.66 & 13.34 \\
\hline Omission of third singular person"s" & 100 & 50 & 66.66 & 33.34 \\
\hline Omission of possessive " 's" & 120 & 30 & 80 & 20 \\
\hline Omission of copula & 140 & 10 & 93.34 & 6.66 \\
\hline Omission of auxiliary verbs & 243 & 57 & 81 & 19 \\
\hline Omission of prepositions & 991 & 85 & 82.59 & 7.08 \\
\hline
\end{tabular}

TABLE 2.

NUMBER OF ERRORS OF ADDITION AND THEIR FREQUENCIES

\begin{tabular}{|c|c|c|c|c|}
\hline Errors of addition & $\begin{array}{l}\text { Number of } \\
\text { correct } \\
\text { responses }\end{array}$ & $\begin{array}{l}\text { Number of } \\
\text { wrong } \\
\text { responses }\end{array}$ & $\begin{array}{l}\text { Frequency of } \\
\text { correct } \\
\text { responses }\end{array}$ & $\begin{array}{l}\text { Frequency of } \\
\text { wrong } \\
\text { responses }\end{array}$ \\
\hline addition of the definite article "the" & 377 & 23 & 68.54 & 4.18 \\
\hline addition of the indefinite article "alan" & 82 & 61 & 41 & 30.5 \\
\hline addition of prepositions & 991 & 67 & 79.42 & 5.58 \\
\hline addition of plural "s" & 466 & 54 & 77.66 & 9 \\
\hline
\end{tabular}

TABLE 3.

NUMBER OF ERRORS OF SUBSTITUTION

\begin{tabular}{ll}
\hline Errors of substitution & Number of wrong responses \\
Wrong selection of Words & 354 \\
Wrong selection of parts of speech & 48 \\
Wrong selection of tenses & 256 \\
Wrong selection of prepositions & 57 \\
\hline
\end{tabular}

TABLE 4.

NUMBER OF ERRORS OF PERMUTATION

\begin{tabular}{ll}
\hline Errors of permutation & Number of wrong responses \\
Errors of misordering of elements & 303 \\
\hline
\end{tabular}

The tables show the errors resulted from the analysis of translations. According to these tables, wrong selection of words (substitution); misordering of elements (permutation) and incorrect use of tenses are the most frequent linguistic errors of the study.

However, regarding the errors of tenses, it should be mentioned that most of the students used:

a. The present progressive tense instead of the simple present tense (70\%), e.g. Most of the families are going to the parks on Fridays.

b. The simple past tense instead of the past progressive tense (67\%), e.g He usually played football with his elder brother.

c. The simple past tense instead of the present perfect tense (65\%), e.g He increased his awareness of the world.

d. The simple past tense instead of the past perfect tense (63\%), e.g They came by a couple of small horses.

\section{DISCUSSION AND CONCLUSION}

The results of research demonstrated errors related to inaccurate selection of the words (substitution), misordering of elements (permutation), and the wrong selection of tenses (substitution) are the most frequent errors in translation of simple, declarative, affirmative and active Persian sentences. Concerning of incorrect selection of words, it is necessary to mention that most of the students do not have got sufficient knowledge about correct usage of words according to context. For example the students are not familiar to contextual differences of the set of vocabularies such as "clock and hour," "voice and sound", "mistake, wrong and error," "son and boy", "bigger and elder" and etc. The other error included in this research was wrong order of elements which can be said literal translation was the root cause of this kind of error, since the structure of Persian sentences had been exactly translated into English, like "they about the war a bad news received".

In this research, lack of students' knowledge about the use of tenses was quite obvious too, (mentioned in previous section). Another problem was errors related to prepositions (especially adding a preposition) that literal translation in many cases, was the root cause of this sort of errors too. For example "we visited from Mashhad two years ago".

Base on this research, lack of language knowledge is the primary problem of the students. Most of the students intend to compensate their linguistic deficiencies through reading of grammar books. But this solution is not certainly useful solution to remove their language problems.

In reading and comprehension, morphology or even translation classes it would be better to emphasize on learning vocabulary according to context. Even in grammar classes, if there is a possibility to compare with native language structures, for recognizing practical use of grammar structures, learners should compare them. 


\section{REFERENCES}

[1] Burt, K.M., \& C. Kiparsky. (1974). The Gooficon, Mass: Newbury House Publishers.

[2] Corder, S.P. (1973). Introducing Applied Linguistics (PP. 274-277). Harmondsworth: Penguin.

[3] Larose, R. (1989). The'ories Contemporaines de la Traduction, Quebec: Presses de L'Universite' du Que'bec.

[4] Mahmoodzadeh, K. (2003). Directionality in Interpreting. Journal of Translation Studies, 1.2, 42-44.

[5] Menck, P. (1991). Looking into Classrooms: Papers on Didactics. (PP. 147-148). Albex Publishing Corporation: Printed in The United States of America.

[6] Mirza Ibrahim Tehrani, F. (2003). Flaws in Translation Programs in Iran. Journal of Translation Studies, 1.2, 89-90.

[7] Newmark, P. (1988). A Textbook of Translation. New York and London: Prentice-Hall.

[8] Nord, C. (1991). Text Analysis in Translation. Amesterdam: Rodopi.

[9] Nord, C. (1997). Translating as a Purposeful Activity: Functionalist Approaches Explained. Manchester: st. Jerome.

[10] Pym, A. (1992). Translation Error Analysis and the Interface with Language Teaching. Published in The Teaching of Translation. Ed. Cay Dollerup and Anne Loddegard, Amesterdam: John Benjamins.

[11] Sager, J. C. (1983). Quality and Standards - The Evaluation of Translations: The Translator's Handbook, London: Aslib.

[12] Toury, G. (1995). Descriptive Translation Studies and Beyond. Amesterdam and Philadelphia: John Benjamins.

[13] Wilss, W. (1982). The Science of Translation: Problems and Methods. Tubingen: Gunter Narrverlag.

Parisa Farrokh received her M.A. in Linguistics from Shahid Beheshti University, Tehran, Iran.

She is Currently Ph.D. student of Linguistics in Baku State University of Azerbayjan Republic. She is faculty member of Islamic Azad University of Lahijan Branch, Iran.

She has Published two books as well as one article. [1] Farrokh, P. (2006). The Basic Concepts in Linguistics. Tehran: Avaye Ostad publisher. [2] Farrokh, P. (2008). The Effect of Simplification on Reading Comprehension. Iranian Journal of Roshd Language Teaching, 2.2, 30-34. [3] Farrokh, P. (2009). Studying English Phonetics and Phonology. Tehran: Avaye Ostad Publisher. 